\title{
ILLUMINATION FOR THE EMPEROR'S INTENDED VISIT TO POSTOJNSKA JAMA, SLOVENIA, IN 1856 (AND USED WHEN HE CAME IN 1857?)
}

\section{RAZSVETLITEV POSTOJNSKE JAME OB NAMERAVANEM CESARJEVEM OBISKU 1856 (IN UPORABLJENI 1857?)}

TREVOR R. SHAW ${ }^{1}$

${ }^{1}$ Karst Research Insititute, ZRC SAZU, Titov trg 2, SI-6230 Postojna, Slovenia, e-mail : izrk@zrc-sazu.si

Prejeto / received: 15. 3. 2003 


\section{Abstract \\ UDC: $551.44(091)$ \\ Trevor R. Shaw: Illumination for the Emperor's intended visit to Postojnska jama, Slovenia, in 1856 (and used when he came in 1857?)}

Three documents in the archives of Postojnska jama show that the arrangements for the planned visit of Emperor Franz Joseph to the cave in 1856 included the use of coloured lights and other special illumination as well as glass transparencies for labelling halls and speleothems. Although this visit was cancelled at the last minute, the Emperor did come to the cave 15 weeks later and it is shown that almost certainly the illumination was used then.

Key words: caves, history, royalty, Franz Joseph, illumination, Postojnska jama, Slovenia.

Izvleček

UDK: 551.44(091)

Trevor R. Shaw: Razsvetlitev Postojnske jame ob nameravanem cesarjevem obisku 1856 (in uporabljeni 1857?)

Na podlagi treh listin iz arhiva Postojnske jame je razvidno, da so priprave na načrtovani obisk cesarja Franca Jo•efa 1856, vključevale uporabo barvnih luči in drugih posebnih načinov razsvetljave kot tudi steklenih napisov za označevanje dvoran in kapnikov. Obisk je bil odpovedan v zadnjem trenutku, vendar je prišel cesar v jamo 15 tednov kasneje in zelo verjetno je, da so omenjeno razsvetljavo uporabili ob tej priliki.

Ključne besede: jame, zgodovina, visoka oseba, Franc Jo•ef, razsvetljava, Postojnska jama, Slovenija. 
The visit to Postojnska jama by Emperor Franz Joseph and Empress Elisabeth in March 1857 is quite well known (Shaw \& Čuk 2002, 16-20). Much less familiar are the preparations made the year before that for a state visit to the cave which was cancelled at the last moment.

The imperial couple did indeed come to Postojna as planned on 20 November 1856 . They travelled from Ljubljana by the newly constructed railway which was not opened for public use until the following year. The journey took two and a half hours. They were met at the railway station by the usual dignitaries and escorted to the town. The cave visit, however, had been omitted from the final programme, to enable them to make a state visit to Seno•ece on the same day. The Emperor promised that they would return to see the cave the next year and they did so on 11 March 1857 on their way back from Italy (Costa 1857, 78-79).

\section{PREPARATIONS FOR THE 1856 CAVE VISIT}

Meanwhile, preparations for the cave visit had been going forward. Less than two weeks before the expected visit a newspaper report dated 8 November stated:

This afternoon, accompanying court counsellor Count Hochenwart who is in charge of all the preparations and decorations in the cave for the Emperor's visit, we walked through the magnificent underground world. We went through the 7 " $\mathrm{km}$ long cave with all the new arrangements, and we also saw the places chosen for special beautification. We can say that everything is well prepared and no one who will be in the cave on that day will be able to forget their impressions. We will not describe here all the new installations in the cave, which will be illuminated with $672 \mathrm{~kg}$ of candles and 5000 lamps.

(Anon. 1856)

Something is known of the "special beautification" mentioned, from papers in the archives of Postojnska jama, now held at the Karst Research Institute in Postojna. It seems that a very large number of coloured lights were to be used. Most were simply described as glass lamps of various colours, and there were also a few more complicated items such as a "sun" and a "laurel wreath" as well as what may have been illuminated glass name signs for parts of the cave. They were supplied by the firm of Franz Roessmann, an agency or depot in Ljubljana (no address given) who were evidently (Fig. 2) suppliers of china, earthenware, glass and mirrors.

After the fruitless installation of all these for the imperial visit that never was, those items that had survived being unpacked and handled in the unfriendly cave environment were, in due course, sent back to the supplier and the missing items were listed in another document.

German script of the mid $19^{\text {th }}$ century is notoriously difficult to read, especially when it has been written in haste. The three archival source documents for what we know of these arrangements 
are therefore reproduced here in facsimile as Figures 1, 2 and 3, in case the reading given in this paper should be questioned. Translations by the German-born American science historian Rudolph Reinbacher, are given in Appendices I to III with additional interpretation by the author.

The documents, in approximate date order, are :

- A part-printed delivery note dated 8 November 1856 ;

- A manuscript list of locations, mainly for the illuminated names, dated 1856 in pencil in a later (archivist's?) hand;

- A list of items missing from the goods returned, dated 27 April 1857.

For convenience the first and last documents, listing items supplied and those never returned, are considered together; while the lengthy list of locations for special illumination is discussed afterwards.

\section{THE ITEMS SUPPLIED}

The first document (Fig 1 and translation in Appendix I) is relatively simple, listing the items despatched to the cave management, mostly white and coloured lamps and some special display items. It is dated 8 November 1856. The expression, "filled illumination glasses" of the various colours, indicates that they were filled with wax and with a wick ready for lighting, as are the lamps sold today for putting on graves, especially on All Souls' Day (31 October). It is, or was, a custom in parts of Germany to decorate whole towns with such coloured lights on special occasions; a spectacular example was the festival "Der Rhein in Flammen" (The Rhine on Fire) near St. Goar, where every window facing the river had as many coloured glass lights as would fit on the sills (Reinbacher 2002)). There is no mention in this document of any transparencies that could be used to illuminate the names of parts of the cave.

The document in Fig. 2 and Appendix II is a statement dated 27 April 1857 listing the items missing from the shipment returned to Franz Roessmann in Ljubljana. The content is selfexplanatory and the losses are not really surprising considering the cave conditions, the probable speed of unpacking, and low morale after the Emperor's non-arrival. This is the only document where the "prism stones" are mentioned. Presumably they are of cut glass like those that hang from chandeliers, but here they are associated with the "transparencies" used for illumination of place names in the cave. Their being listed separately suggests that they were supplied loose to be suspended, as with chandeliers, rather than being fixed to the transparencies like reflectors on road signs. The Austrian currency used in this document is gulden or florins ( $\mathrm{Fl})$, containing 60 Kreutzers.

From the fact that the goods were delivered "free" according to the delivery note (Appendix I) and only those not returned were charged for (Appendix II), it is evident that the items were supplied on loan. A rental charge would almost certainly have been made, but no documentary evidence of that has been traced. 


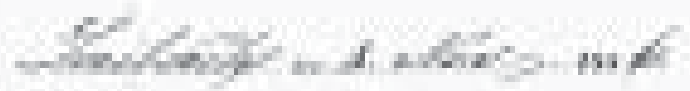

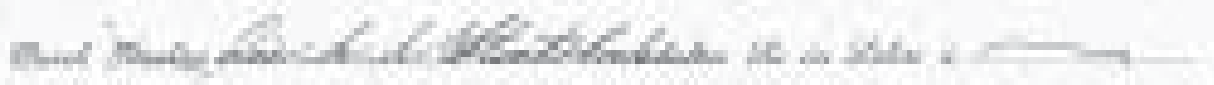

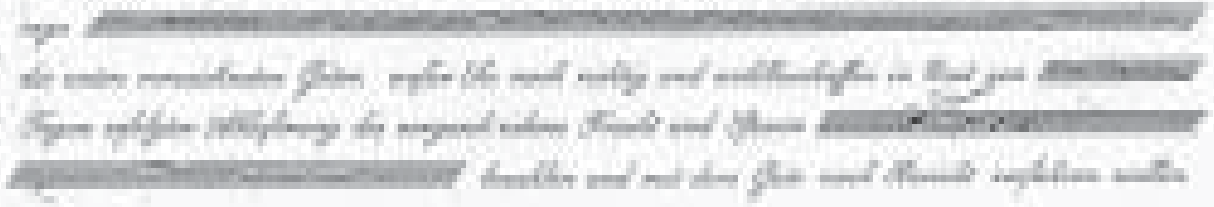

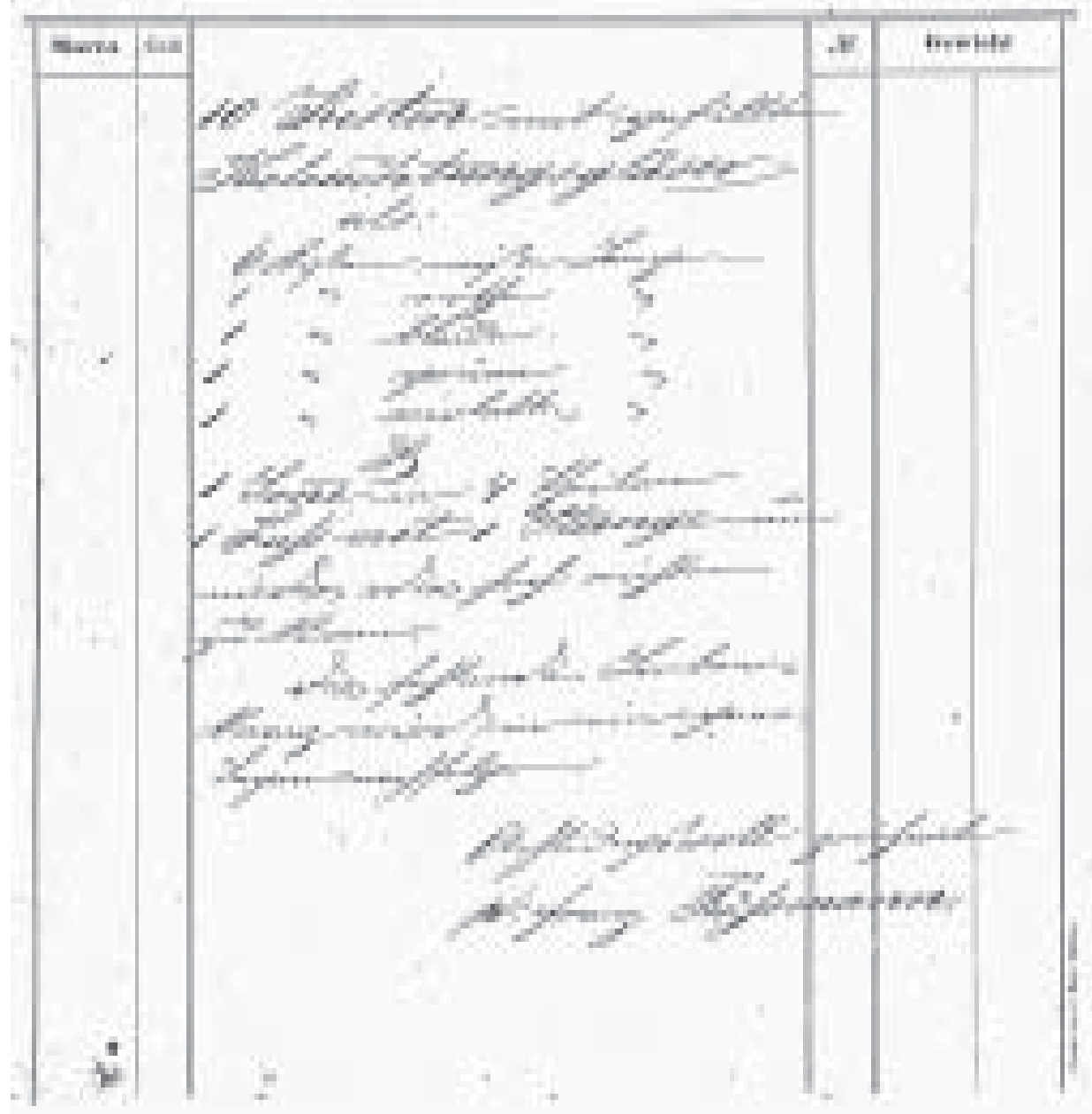

Fig. 1: Delivery Note dated 8 November 1856 (archives of Postojnska jama). 


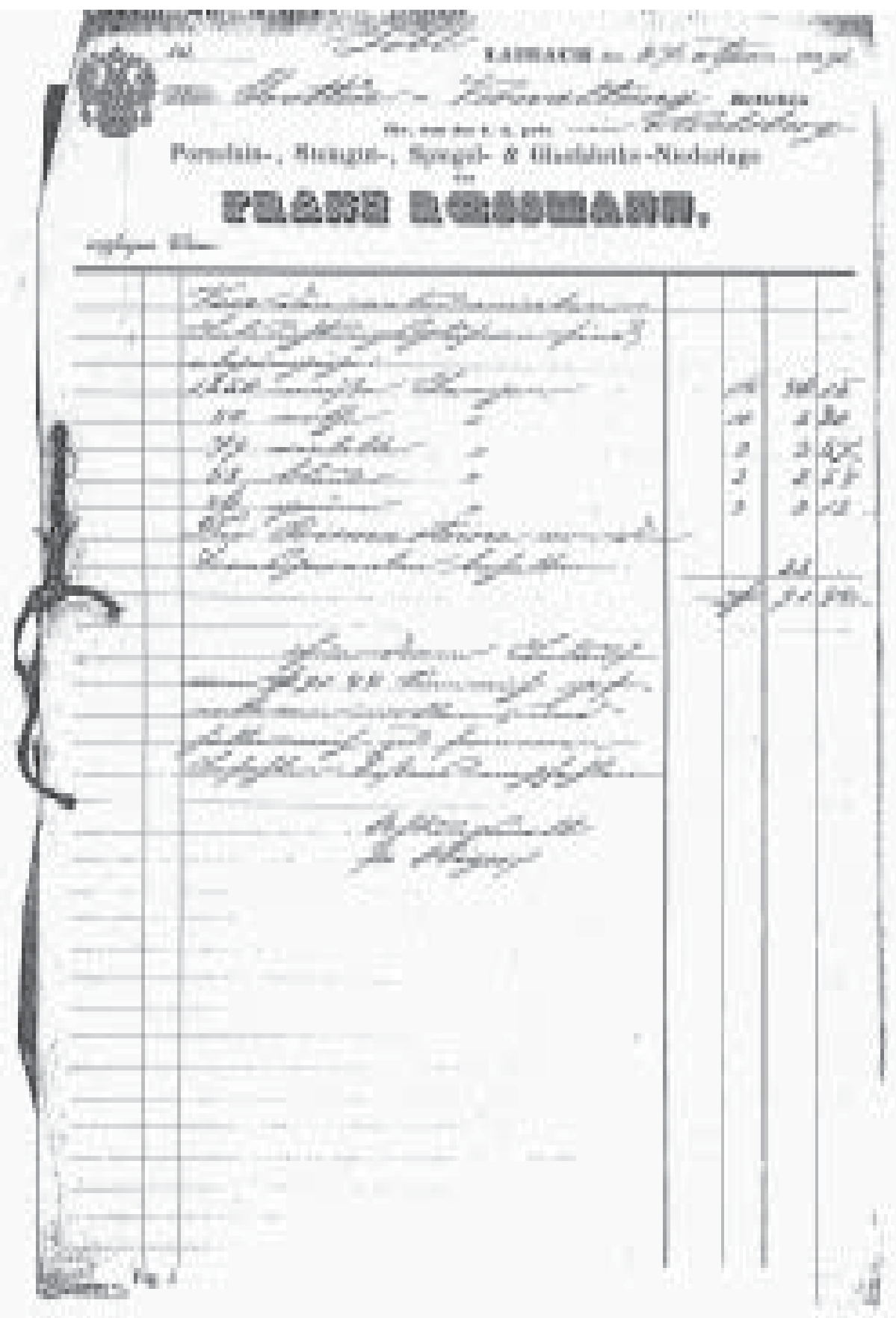

Fig. 2: List of items not returned, dated 27 April 1857 (archives of Postojnska jama). 


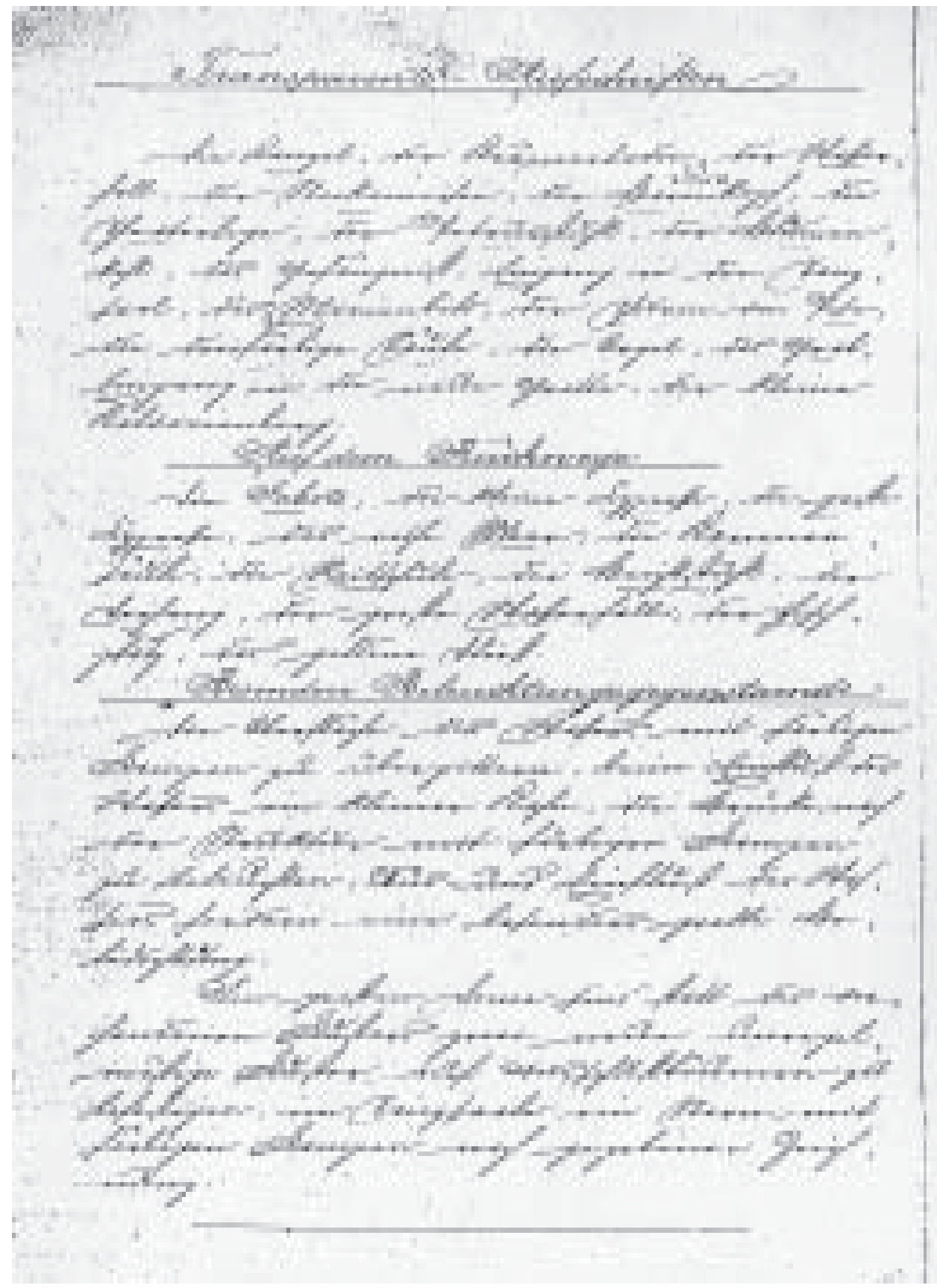

Fig. 3: 1856 list of places to have name transparencies or special illumination (archives of Postojnska jama). 


\section{THE PLACES WITH SPECIAL ILLUMINATION}

The remaining document (Fig. 3 and Appendix III), not precisely dated but evidently of 1856, is mainly a list of locations in the cave which were to be provided with illuminated transparent glass signs. This is followed by details of the special illumination planned for the large halls, Veliki dom and Kongresna dvorana.

The first half of the document, listing the places to have illuminated signs, is headed "Transparents - Aufschriften" (Name Transparencies) and the names are those of special groups of stalagmites, etc., such as are given imaginative names in all caves shown to the public. Much of this document is specially difficult to read and the places names have been confirmed by comparison with those on Eunike's 1858 plan (in Costa 1858). In Appendix III the original German names have therefore been transcribed, together with literal translations into English and the Slovene names given in the nearcontemporary Slovene translation of Eunike's 1858 plan (in Costa 1863), as well as the present-day Slovene names where these are known to be different.

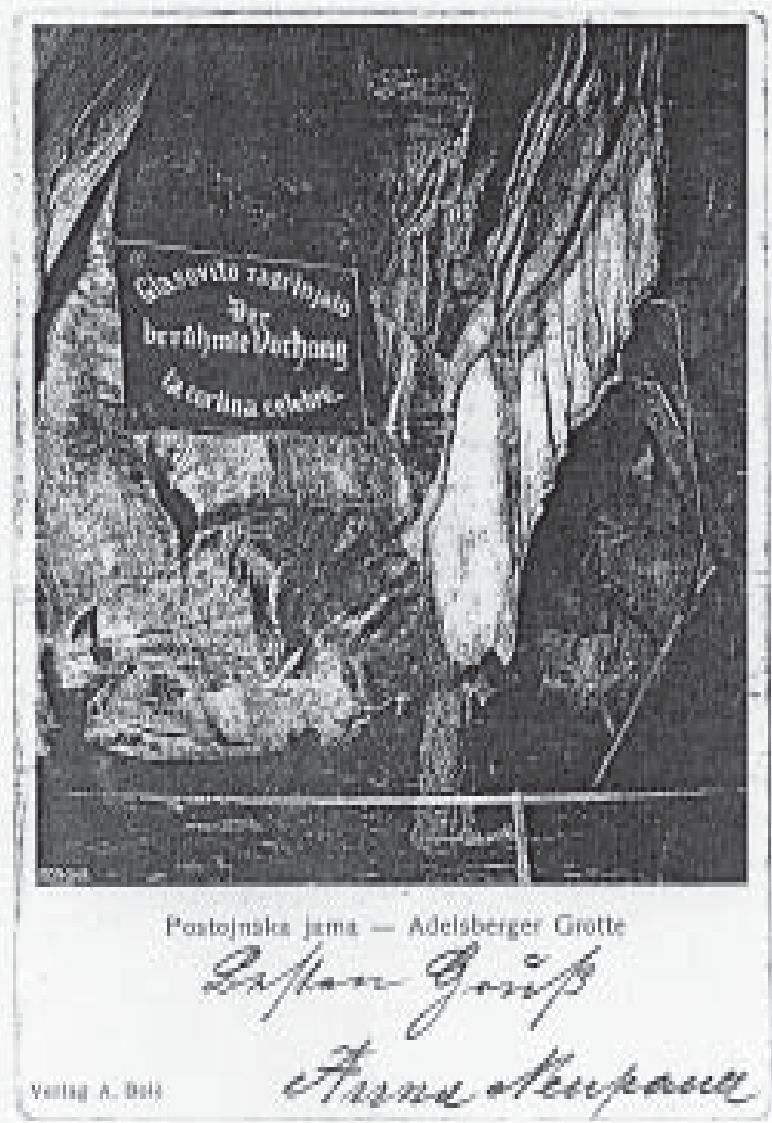

Fig. 4: The Vorhang (curtain) in the 1890s, with a typical name board used at that time.
Photographs taken later in the $19^{\text {th }}$ century (e.g. Fig. 4) shown that by then the places were labelled with painted boards. Perhaps they already were in 1856 , but it is clear that for the visit of the Emperor they were to be given special signs, illuminated and with transparencies which may have carried the lettering or have been coloured to adorn a name board behind. These signs were evidently enhanced by glittering "prism stones", not mentioned in this document but only in the one of 1857 (Appendix II).

The list of items supplied makes no mention of any such transparent signs. Perhaps, therefore, the transparencies were supplied separately with documentation which has not survived.

Almost all the second half of this document, headed "Besondere Beleuchtungsgegenstaende" (Places Specially Illuminated), refers to the vast chamber of Veliki dom where the water of the broad underground river Pivka enters from one side and flows out on the 
other. It is only about $150 \mathrm{~m}$ from the cave entrance and modern visitors see it when they leave the cave train at the end of their tour. At the very end of this section a special arrangement of coloured lights for Kongresna dvorana is proposed.

\section{WERE THESE LAMPS ETC. KEPT AND USED FOR THE 1857 VISIT?}

Now, were these coloured lamps etc. returned to Ljubljana straight away after the cancelled visit of November 1856, or were they retained for use for when the visit did take place 15 weeks later, on 11 March 1857? The latter would be the natural thing to do, for the plans had been made, the material obtained and the requirement was the same. This would be consistent with the date (27 April 1857) of the list of items missing from those returned if they were not despatched until after the real visit. Furthermore, when this visit did take place "an illuminated inscription marked the entrance into the Male jame" (Shaw \& Čuk 2002, 18-19, based on Anon. 1857), one of the places planned to have a name transparency in 1856. Also (Costa 1857, 107), an "Eingang in den Tanzsaal" (see Appendix III.) transparency was in place during the 1957 visit. Thus it is almost certain that the lamps and other equipment were used in 1857 and that these documents therefore provide significant new information about the appearance of the cave during that visit.

\section{CONCLUSION}

At first it seemed that these papers document a disappointing episode in the history of Postojnska jama, when hard work, money and local pride all came to nothing when the imperial visit was cancelled. Less than five months later, on 11 March 1857, the very successful and well publicized visit by the Emperor and the young Empress Elisabeth must have restored everyone's spirits. Almost certainly, too, the special illumination items obtained for the intended 1856 visit were used then.

\section{ACKNOWLEDGEMENTS}

Without Rudy Reinbacher's ability to read German script and his willingness to translate it, this paper could never have been written. Alenka Čuk and the Notranjski muzej in Postojna provided the contemporary newspaper account of the preparations, and Stephan Angsüsser of München and Bernd Kliebhan of Münzenberg also advised on language matters.

\section{REFERENCES}

Anon., 1856 : Novice, 12 November, Ljubljana.

Anon., 1857 : Novice, 14 March, Ljubljana.

Costa, E.H., 1857 : Denkbuch der anwesenheit allerhöchstihrer Majestäten Franz Josef und Elisabeth im Herzogthume Krain. - Kleinmayr \& Bamberg, p.140, lxxi, Ljubljana.

Costa, E.H., 1858 : Die Adelsberger Grotte. - p. 54, [i], Ljubljana. (A few of the places named in Appendix III of this paper are not shown on Eunike's map but are mentioned in Costa's text.)

Costa, E.H., 1863 : Postojnska jama. - J. Giontini, p.48, Ljubljana. (A few of the places named in Appendix III of this paper are not shown on Eunike's map but are mentioned in Costa's text.)

Reinbacher, W.R., 2002 : letter to T.R. Shaw dated 5 October

Shaw, T.R. \& A. Čuk, 2002 : Royal and other noble visitors to Postojnska jama 1819 - 1945. - Acta carsologica, 31 (1), supplementum I, p. 106 Ljubljana. 


\title{
APPENDIX I - DELIVERY NOTE, DATED 8 NOVEMBER 1856
}

Laibach, 8 November 1856

By the Imperial and Royal State Railway at a cost of - $\quad$ you receive the listed goods for which, if correct and in good condition, you will pay for freight and cost within - days the amount of free and will use the goods as stated.

10 crates with filled illumination glasses as shown below:

\author{
6 crates of white lamps \\ 1 crate of red lamps \\ 1 crate of blue lamps \\ 1 crate of green lamps \\ 1 crate of violet lamps \\ 1 sun in four parts, with \\ 1 base, with a pole for installing [it] higher or lower
}

The missing laurel wreath will follow in a few days.

signed, with regards

for Franz Rössmann

\section{APPENDIX II - LIST OF ITEMS NOT RETURNED, DATED 27 APRIL 1857}

Laibach, 27 April 1857

[to] the respected Adelsberg Cave Management

from Franz Roessmann, agent for china, earthenware, glass and mirrors

Of the illumination glasses returned, there are missing:

$$
\text { [cost for each }(\mathrm{Kr})] \quad \text { [total charge }(\mathrm{Fl} . \mathrm{Kr})]
$$

1850 white lamps

50 red lamps

79 violet lamps

58 blue lamps

46 green lamps
$1 "$

10

3

3

3
46.15

3.57

2.54

2.18

28.00

Fl. $\quad 91.44$

Would you please pay us the amount due of Fl. 91.44.

We recommend ourselves for further orders.

With regards,

signed : the above 


\section{APPENDIX III - LOCATIONS DOCUMENT OF 1856}

\begin{tabular}{|c|c|c|}
\hline \multicolumn{3}{|c|}{ Transparency Names } \\
\hline \multirow[t]{9}{*}{ [names transcribed from archives } & [English translation] & [Slovene name. \\
\hline & & Contemporary names \\
\hline & & taken from the 1863 \\
\hline & & Slovene edition (Costa \\
\hline & & 1863) of the 1858 Eunike \\
\hline & & map are denoted by *. \\
\hline & & Recent names, if \\
\hline & & different, have no \\
\hline & & asterisk] \\
\hline \multicolumn{3}{|l|}{ [On the way in to the cave] } \\
\hline Die Kanzel & Pulpit & Leca*, Pri॰nica \\
\hline \multirow{3}{*}{$\begin{array}{l}\text { Der Kolonialwaren } \\
\text { [then usually named } \\
\text { Fleischbank] }\end{array}$} & Groceries (then & Mesnica* \\
\hline & usually called the & \\
\hline & Butcher's Stall) & \\
\hline Der [kleine] Wasserfall & [Small] Waterfall & Mali slap* \\
\hline Der Stock im Eisen & Iron Staff & $\begin{array}{l}\text { Okovani kol*, Porobek } \\
\text { v •elezu }\end{array}$ \\
\hline Der Löwenkopf & Lion's Head & Levja glava* \\
\hline Die Theaterloge & Theatre Box & Lo•a* \\
\hline Der Petri Stuhl & St Peter's Chair & Sv. Petra stol* \\
\hline Der Blumenkohl & Cauliflower & Karfijol* \\
\hline Das Gefängnis & Prison & Ječa* \\
\hline \multirow[t]{2}{*}{ Eingang in den Tanzsaal } & Entrance to Ball & Plesišče*, Plesna \\
\hline & Room & $\begin{array}{l}\text { dvorana, Kongresna } \\
\text { dvorana }\end{array}$ \\
\hline \multirow[t]{2}{*}{ Das Marienbild } & Image of the & Podoba matere bo $\cdot \mathrm{je}^{*}$ \\
\hline & Virgin Mary & \\
\hline Der Thurm von Pisa & $\begin{array}{l}\text { [Leaning] Tower } \\
\text { of Pisa }\end{array}$ & Stolp iz Pize* \\
\hline \multirow{2}{*}{ Die dreifarbige Säule } & Three-coloured & Trebarvni steber* \\
\hline & Column & \\
\hline Die Orgel & Organ & Orgelski piščali* \\
\hline \multirow[t]{2}{*}{ Das Grab } & Sepulchre, & Grob*, Baldahin \\
\hline & [canopied] Tomb & \\
\hline \multirow[t]{2}{*}{ Eingang in die neue Grotte } & Entrance to the New & Razpotje \\
\hline & Cave & \\
\hline \multirow[t]{2}{*}{ Der kleine Kalvarienberg } & Small Calvary & Mala gora Kalvarija*, \\
\hline & Mountain & Mala Kalvarija \\
\hline
\end{tabular}


On the way back

Die Jabots

Jabots (frills)

Kre•eljci*, Mala zavesa

Die kleine Zypresse

Small Cypress

Mala cipresa*

Die grosse Zypresse

Large Cypress

Velika cipresa*

Das rothe Meer

The Red Sea

Rudeče morje*

Die Kanonensäule

Cannon Column

Topov steber*

Die Reitschule

Riding School

Jezdnica*

Der Beichtstuhl

Confessional

[S]povednica*

Der Vorhang

Curtain

Zagrinjalo*, Zastor,

Zavesa

Der grosse Wasserfall

Big Waterfall

Veliki slap*

Der Fischplatz

Fish Market

Ribji trg*

Das goldene Vliess

Golden Fleece

Zlato runo*

\section{Places Specially Illuminated}

The surface of the water with a grid of coloured lamps over it; near the inflow of the water, a small boat; the bridge with coloured lamps to light it; the entry and exit of the water require especially bright illumination.

Instead of the existing [single] chandelier in the Grosse Dom [Veliki dom], new irregularshaped chandeliers should be mounted on rods protruding [from the walls]. In the Tanzsaal [Kongresna dvorana] there should be an arrangement of coloured lamps as shown on the attached sketch [no longer present]. 